Article

\title{
Nutrient Extraction in Pansy Fertigated with Pure, Diluted, Depurated and Phytodepurated Leachates from Municipal Solid Waste
}

\author{
Blanca María Plaza ${ }^{1}$, Rita Maggini ${ }^{2}$, Eva Borghesi ${ }^{2}$, Alberto Pardossi ${ }^{2} \oplus$, María Teresa Lao ${ }^{1}$ \\ and Silvia Jiménez-Becker $1, *$ (D) \\ 1 Department of Agronomy, School of Engineering, CIAIMBITAL, Agrifood Campus of International \\ Excellence ceiA3, University of Almeria, Ctra. Sacramento s/n, 04120 Almeria, Spain; \\ blancamph@yahoo.es (B.M.P.); mtlao@ual.es (M.T.L.) \\ 2 Department of Agriculture, Food and Environment (DAFE), University of Pisa (UNIPI), Via del Borghetto 80, \\ 56124 Pisa, Italy; rita.maggini@unipi.it (R.M.); evaborghesi@libero.it (E.B.); alberto.pardossi@unipi.it (A.P.) \\ * Correspondence: sbecker@ual.es; Tel.: +34-950-015-952
}

Received: 6 November 2020; Accepted: 30 November 2020; Published: 3 December 2020

\begin{abstract}
The disposal of municipal solid waste (MSW) in landfills might result in serious environmental pollution. The goal of the present assay was to assess if MSW wastewater (pure or treated) can be used as a potential source for fertilizers, studying its effects on plant biometric parameters as well as on anion concentrations and anion partitioning of the bedding plant Viola $\times$ wittrockiana Gams. (pansy), to detect possible harmful impacts on plants. The treatments tested were: $\mathrm{W}_{9.0}$ (pure wastewater, EC $9.0 \mathrm{dS} \mathrm{m}^{-1}$ ), $\mathrm{W}_{4.5}$ (diluted wastewater, EC $4.5 \mathrm{dS} \mathrm{m}^{-1}$ ), $\mathrm{DW}_{4.5}$ (depurated wastewater, EC $4.5 \mathrm{dS} \mathrm{m}^{-1}$ ), $\mathrm{PW}_{4.5}$ (phytodepurated wastewater, EC $4.5 \mathrm{dS} \mathrm{m}^{-1}$ ), and T (tap water, the control, EC $1.5 \mathrm{dS} \mathrm{m}^{-1}$ ). The treatment with pure wastewater negatively affected plant fresh weight, water content (on a fresh weight basis), leaf area, plant height and width, and the number of leaves and flowers due to an accumulation of $\mathrm{SO}_{4}{ }^{2-}$ in plant tissues. Phytodepurated wastewater improved plant fresh weight, water content, plant height and width, the number of leaves and flowers, and reduced the leaf area because this treatment decreased $\mathrm{SO}_{4}{ }^{2-}$ concentrations in wastewater by half. Pansy plants also showed high levels of nutrients $(\mathrm{N}, \mathrm{P}$, and $\mathrm{Mg})$ when compared with fertigation with pure and diluted landfill leachate. These results show that phytodepurated wastewater from MSW can be used for the fertigation of pansy plants.
\end{abstract}

Keywords: landfill; phytodepuration; phytopurification; anions content; cations content; sulphate; salinity

\section{Introduction}

With the development of the economy and the improvements in living standards, the problem of garbage has become increasingly prominent. It is expected that with the on-going increases in population and per capita daily garbage production, the amount of municipal solid waste (MSW) will continue to grow rapidly, and the current garbage disposal service model will not be able to solve the garbage problem effectively [1].

Inadequate disposal of MSW might lead to serious environmental pollution. Although landfilling is a commonly used disposal procedure, composting and recycling methods are preferable [2]. Moreover, one of the consequences of MSW deposition is the production of landfill leachate. Its volume and composition are determined by numerous factors, including waste composition, landfill age, and the volume of precipitation [3]. Municipal solid waste is heterogeneous in nature [4]. Leachate may 
contain a number of mineral and organic compounds, the volume of which must be regularly controlled [3]. Leachate from municipal wastes contains C, N, P, K, and trace elements that can be used as nutrients by plants; their use as fertilizers would reduce the consumption of commercial fertilizers, which are expensive to produce both in terms of cost and energy [5]. Nevertheless, leachate produced from hazardous waste landfills (HWLs) is toxic and contains high levels of refractory organics, ammoniacal-nitrogen, heavy metals, inorganic salts, and organo-chloro compounds [6].

The Urban Waste Water Treatment Directive (UWWTD) is one of the crucial policy instruments under the EU water acquis for safeguarding the environment and human health. The steps towards the implementation of the UWWTD over the past 25 years have played a substantial role in increasing the quality of waters in EU rivers, lakes, and seas. The percentage of treated wastewater that is reused ranges from $0.08 \%$ in the UK to $97.00 \%$ in Cyprus, with an average of $2.00 \%$ in the EU. Reuse mainly occurs in agriculture, and occasionally in industry and aquifer feeding [7]. It is also required to evaluate whether treated effluents from MSW can be reutilized for agriculture [8].

Over the last 20 years, phytoremediation (also known as phytodepuration), referring to all plant-based technologies using green plants to remediate and rehabilitate MSW landfills and dumpsites, has appeared as a potential solution [9] for landfill leachate reuse. For example, Nuttall's alkaligrass (Puccinellia nuttalliana (Schult.) Hitchc.) and broadleaf cattail (Typha latifolia L.) irrigated with landfill leachate have, respectively, $2.13 \%$ and $19.70 \%$ more biomass yield than plants irrigated with tap water (control), and these plants accumulate, respectively, $120.14 \%$ and $94.47 \%$ more $\mathrm{Cl}^{-}$than the control; moreover, soil EC is reduced by $71.70 \%$ and $45.36 \%$, respectively. This research proved that the use of North American native halophytes could be a cost-effective and encouraging approach for the phytoremediation of landfill leachate [10]. On the other hand, in a study carried out in Laos, approximately $50 \%$ of the MSW landfill was organic matter. For the elephant grass (Pennisetum purpureum Schumach.), the accumulation of heavy metals in all plant parts are extreme [11]. These data show that phytoremediation is an efficient treatment technique, due to its low cost and ease of operation and maintenance [12,13]. Populus selections are ideal for production systems that reuse and recycle wastewaters as irrigation and fertilization, given their fast growth, extensive root systems, and high-water usage rates [14].

The goal of this assay was to assess if MSW leachates (pure or treated) can be used as a potential source for fertilizers. The influence of pure, diluted, sand depurated and phytodepurated leachates, contrasted with tap water, on Viola $\times$ wittrockiana Gams. (commonly known as pansy, a top-selling pot species in wholesale markets) plant biometric parameters, as well as on anion and cation extraction, were studied, with the intention of detecting potential harmful impacts on this ornamental species.

\section{Materials and Methods}

\subsection{Phytodepuration Station}

The wastewater used in this assay proceeded from MSW that were collected in an open landfill belonging to the Rosignano Energia Ambiente company $\left(43^{\circ} 23^{\prime} 11.5^{\prime \prime} \mathrm{N} 10^{\circ} 28^{\prime} 06.7^{\prime \prime} \mathrm{E}\right)$, located in the region of Tuscany (Italy). Every 2 weeks, this leachate $(\mathrm{W})$ was obtained from a pond where it had been stored and transported to the phytodepuration station (Figure 1a), which was located in the experimental field of the Department of Agriculture, Food and Environment (DAFE) $\left(43^{\circ} 42^{\prime} 15.5^{\prime \prime}\right.$ $\mathrm{N} 10^{\circ} 25^{\prime} 38.4^{\prime \prime} \mathrm{E}$ ) of the University of Pisa (Italy). There, $0.80 \mathrm{~m} \times 0.60 \mathrm{~m} \times 0.50 \mathrm{~m}$ lysimeters, with a pipe at the base for the collection of the water discharge, were filled with a $20 \mathrm{~cm}$ expanded clay layer (at the bottom) and sand. They were irrigated with landfill leachate and the drainage was collected, obtaining the depurated drainage water (DW). Moreover, paleyellow iris (Iris pseudacorus L.), Lombardy poplar (Populus nigra L.), and common reed (Phragmites australis (Cav.) Trin. ex Steud.) plants were cultivated in the same type of lysimeter (each species in a different tank) and they were also irrigated with landfill leachate ( $30 \mathrm{~L}$ per lysimeter); analogous volumes were collected from each lysimeter and then blended to obtain the phytodepurated drainage water (PW). Standard fertilization 
was applied every 2 weeks to both types of lysimeter because these species have a high nutrient removal efficiency and the concentration of some nutrients, such as $\mathrm{NO}_{3}{ }^{-}$and $\mathrm{PO}_{4}{ }^{3-}$, was very low in the pure wastewater. The trial took place outdoors.

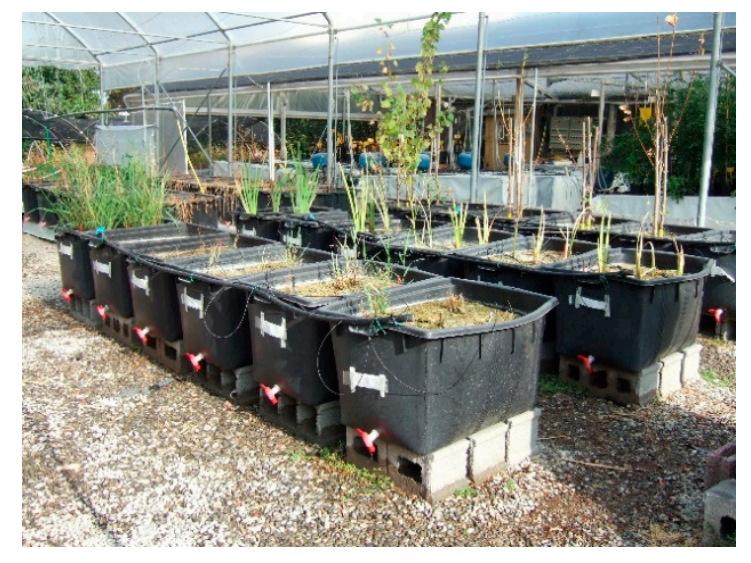

(a)

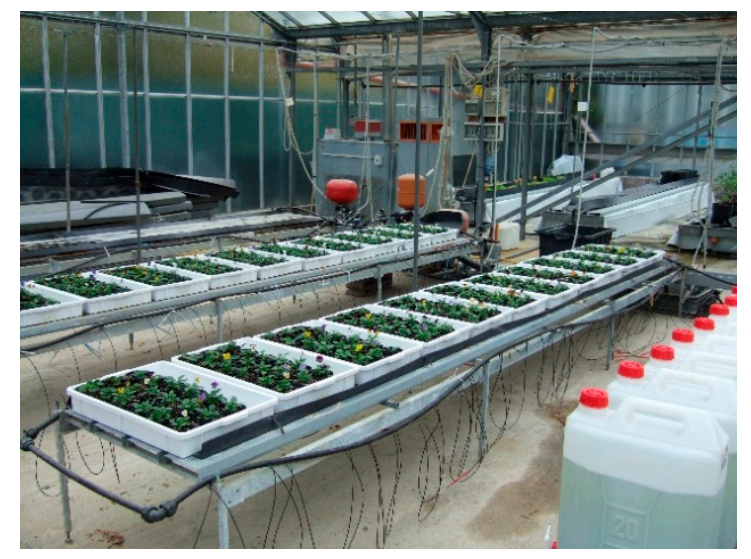

(b)

Figure 1. (a) Phytodepuration station and (b) pansy plants cultivated in the greenhouse under the different treatments tested.

\subsection{Treatments}

Pansy were transplanted in $10 \mathrm{~cm}$ diameter plastic pots, using a mixture of peat and perlite (3:1 $v: v)$ as the substrate, in a greenhouse situated in the experimental field of the DAFE, in September. For two weeks, the plants were fertigated every 3 days, using a standard nutrient solution $\left(\mathrm{N}-\mathrm{NO}_{3}\right.$ 10.0 mM, N-NH 1.0 mM, P 1.0 mM, K 5.0 mM, Ca 3.0 mM, Mg 1.5 mM, S-SO 1.8 mM, Cl 0.5 mM, Fe $45.0 \mu \mathrm{M}, \mathrm{Cu} 2.4 \mu \mathrm{M}, \mathrm{Zn} 2.3 \mu \mathrm{M}$ and $\mathrm{Mn} 7.3 \mu \mathrm{M}$ ), applying $40 \mathrm{~mL}$ per plant. After that, the pots were positioned in $60 \mathrm{~cm} \times 40 \mathrm{~cm}$ plastic trays on raised benches (Figure 1b). The treatments tested were: $\mathrm{W}_{9.0}$ (pure wastewater, EC $9.0 \mathrm{dS} \mathrm{m}^{-1}$ ), $\mathrm{W}_{4.5}$ (diluted wastewater, EC $4.5 \mathrm{dS} \mathrm{m}^{-1}$ ), DW 4.5 (depurated water, EC $4.5 \mathrm{dS} \mathrm{m}^{-1}$ ), $\mathrm{PW}_{4.5}$ (phytodepurated water, EC $4.5 \mathrm{dS} \mathrm{m}^{-1}$ ) and $\mathrm{T}$ (tap water, the control, EC $1.5 \mathrm{dS} \mathrm{m}^{-1}$ ). The value of $4.5 \mathrm{dS} \mathrm{m}^{-1}$ was achieved by dilution of the $\mathrm{W}, \mathrm{DW}$, and PW drainage obtained in the phytodepuration station with tap water. After the fertigation solutions were prepared, they were kept in $20 \mathrm{~L}$ plastic jerry cans. Plants were fertigated by sub-irrigation (water and nutrient solution provided at the base of the container rises by capillary action through holes in the bottom and is absorbed by the growing media). Fertigation frequency and volume were based on plant requirements, ranging from $85.0 \mathrm{~mL}$ per plant every 3 days at the beginning of the trial, to $55.0 \mathrm{~mL}$ per plant every 7 days at the end of the cultivation (November).

\subsection{Sampling and Analyses}

\subsubsection{Fertigation Solutions}

Throughout the cultivation period, the 5 fertigation solutions were analyzed 3 times (each time they were prepared) for anions $\left(\mathrm{NO}_{3}{ }^{-}, \mathrm{PO}_{4}{ }^{3-}, \mathrm{Cl}^{-}\right.$, and $\left.\mathrm{SO}_{4}{ }^{2-}\right)$ and cations $\left(\mathrm{Ca}^{2+}, \mathrm{Mg}^{2+}, \mathrm{Na}^{+}\right.$, and $\left.\mathrm{K}^{+}\right)$. Sulfate and $\mathrm{Cl}^{-}$were analyzed by chromatography (Dionex DX-120 (Sunnyvale, CA, USA), with the column for anions ion pack $4 \times 250 \mathrm{~mm}$ AS 22). Nitrate was analyzed with the method described by Cataldo et al. [15] and $\mathrm{PO}_{4}{ }^{3-}$ by the molybdate method (by complex formation with ammonium molybdate followed by reduction with stannous chloride), using a Shimadzu UV-1204 UV/VIS spectrophotometer (Shimadzu Scientific Instruments Inc., Columbia, MD, USA). Cations were analyzed by atomic absorption spectrophotometry (AAS) (model SpectrAA240FS, Varian Australia Pty Ltd, Mulgrave, Australia). pH and EC were also determined. A Crison MicropH 2001 pH-meter (Crison, 
Barcelona, Spain) and an EC with a Crison Micro CM 2200 conductivity-meter (Crison, Barcelona, Spain) were employed to measure $\mathrm{pH}$ and $\mathrm{EC}$, respectively.

\subsubsection{Substrate Solution}

At the end of the trial, 4 samples of substrate per treatment were randomly taken. $\mathrm{pH}, \mathrm{EC}$, anions, and cations were determined in the aqueous extract 10:1 (v:v), obtained by the addition of $10 \mathrm{~g}$ of dried substrate to $100 \mathrm{~mL}$ of water, followed by shaking and filtrating. Both $\mathrm{SO}_{4}{ }^{2-}$ and $\mathrm{Cl}^{-}$were analyzed with an ion chromatograph (Dionex DX-120 (Sunnyvale, CA, USA), with the column for anions ion pack $4 \times 250 \mathrm{~mm}$ AS 22), $\mathrm{NO}_{3}{ }^{-}$by the Cataldo method [15], and $\mathrm{PO}_{4}{ }^{3-}$ by the molybdate method. Potassium, $\mathrm{Na}^{+}, \mathrm{Ca}^{2+}$ and $\mathrm{Mg}^{2+}$ were analyzed by atomic absorption spectrophotometry (model SpectrAA240FSVarian Australia Pty Ltd, Mulgrave, Australia).

\subsubsection{Plant Biometric Parameters}

Sampling was carried out at the end of the assay, 43 days after transplanting. Plant height $(\mathrm{cm})$ and plant width $(\mathrm{cm})$ were measured using a graduated ruler. Plant height was determined from the base to the tip of the plant. Plant width was calculated as the average value of the maximum and minimum diameter.

After removing the substrate, the plant material was separated into different vegetal fractions: roots, shoots (including stems and leaves), and flowers, which were weighed separately on an Ohaus Adventurer TM scale (Ohaus Corporation, Parsippany, NJ, USA) to determine the fresh weight (FW). The numbers of leaves and flowers were counted, and the leaf area $\left(\mathrm{cm}^{2}\right)$ was measured with a leaf area meter (model MK2, Delta-T Devices, Cambridge, UK).

Afterward, each fraction was dried in an M710 Thermostatic forced oven (F.lli Galli, Milan, Italy), at $75{ }^{\circ} \mathrm{C}$ for $48 \mathrm{~h}$ to determine the dry weight (DW). Four replicates per treatment and 2 plants per replicate were taken. Water content (\%) was calculated on an FW basis, following the formula [16]:

$$
\frac{(F W-D W)}{F W} \times 100
$$

\subsubsection{Plant Tissue}

At the end of the trial, the dried material was ground and divided into three subsamples. The first one was used to determine the soluble ionic forms $\left(\mathrm{NO}_{3}{ }^{-}, \mathrm{SO}_{4}{ }^{2-}\right.$ and $\left.\mathrm{Cl}^{-}\right)$. After its solubilization, $\mathrm{NO}_{3}{ }^{-}$was analyzed with the method described by Cataldo et al. [15] with a Shimadzu UV-1204 UV/VIS spectrophotometer (Shimadzu Scientific Instruments Inc., Columbia, MD, USA). Both $\mathrm{SO}_{4}{ }^{2-}$ and $\mathrm{Cl}^{-}$ were quantified by HPLC (High-Performance Liquid Chromatography; Metrohm 883 Basic IC Plus), using a Metrosep A Supp 4 column (IC conductivity detector range $0-15000 \mu \mathrm{S} \mathrm{cm}^{-1}$ ). The mobile phase was prepared by mixing $190.60 \mathrm{mg}$ of $\mathrm{CO}_{3}{ }^{2-}$ and $142.80 \mathrm{mg}$ of $\mathrm{HCO}_{3}{ }^{-}$and then diluting them in $1 \mathrm{~L}$ of deionized water, acidified with $\mathrm{H}_{2} \mathrm{SO}_{4}(50 \mathrm{mM})$. The second subsample was digested with phospho-sulfuric acid to determine organic $\mathrm{N}$ via the Kjeldahl-Tecator method [17]. Total $\mathrm{N}$ was calculated as the sum of $\mathrm{NO}_{3}{ }^{-}$and organic $\mathrm{N}$. The third subsample was digested (perchloric-nitric digestion); $\mathrm{P}$ was determined by the molybdate method, while $\mathrm{Na}^{+}, \mathrm{K}^{+}, \mathrm{Ca}^{2+}$, and $\mathrm{Mg}^{2+}$ were analyzed by atomic absorption spectrophotometry [18].

\subsection{Experimental Design and Statistical Analysis}

The experiment was analyzed as a completely randomized block design. It was unifactorial (type of fertigation solution), with 4 replicates per treatment and 2 plants per replicate.

A one-way Analysis of Variance (ANOVA) and a Least Significant Difference (LSD) test $(p<0.05)$ were performed, using Statgraphics Centurion 18 (Statpoint Technologies, Inc. Warrenton, VA, USA), to evaluate the differences between treatments, which is represented by lower case letters. 


\section{Results}

\subsection{Irrigation Water Quality}

Table 1 shows the $\mathrm{pH}, \mathrm{EC}$, and ion concentrations of the different fertigation solutions tested in the assay. In all treatments, the nutrient solution $\mathrm{pH}$ was basic, ranging from 8.58 in $\mathrm{T}$ and 9.34 in $\mathrm{W}_{9.0}$; it was higher in $\mathrm{W}_{9.0}, \mathrm{~W}_{4.5}$, and $\mathrm{PW}_{4.5}$. There were $3 \mathrm{EC}$ levels: high $\left(\mathrm{W}_{9.0}\right), 9.09 \mathrm{dS} \mathrm{m}^{-1}$, medium $\left(\mathrm{W}_{4.5}\right.$, $\mathrm{DW}_{4.5}$, and $\mathrm{PW}_{4.5}$ ), with values between 4.54 and $4.76 \mathrm{dS} \mathrm{m}^{-1}$ and low (T), $1.17 \mathrm{dS} \mathrm{m}^{-1}$.

Table 1. Fertigation solution analysis (EC in $\mathrm{dS} \mathrm{m}^{-1}$, concentrations in $\mathrm{mg} \mathrm{L}^{-1}$ ).

\begin{tabular}{cccccc}
\hline Treatment & $\mathbf{W}_{\mathbf{9 . 0}}$ & $\mathbf{W}_{\mathbf{4 . 5}}$ & $\mathbf{D W}_{\mathbf{4 . 5}}$ & $\mathbf{P W}_{\mathbf{4 . 5}}$ & $\mathbf{T}$ \\
\hline $\mathbf{p H}$ & $9.34 \pm 0.14 \mathrm{a}$ & $9.17 \pm 0.25 \mathrm{a}$ & $8.99 \pm 0.38 \mathrm{~b}$ & $9.11 \pm 0.34 \mathrm{a}$ & $8.58 \pm 0.17 \mathrm{~b}$ \\
$\mathbf{E C}$ & $9.09 \pm 0.16 \mathrm{a}$ & $4.76 \pm 0.19 \mathrm{~b}$ & $4.61 \pm 0.04 \mathrm{~b}$ & $4.54 \pm 0.16 \mathrm{~b}$ & $1.17 \pm 0.14 \mathrm{c}$ \\
$\mathbf{N O}_{3}{ }^{-}$ & $28.14 \pm 5.13 \mathrm{~b}$ & $31.19 \pm 9.57 \mathrm{~b}$ & $96.73 \pm 18.22 \mathrm{a}$ & $96.30 \pm 8.44 \mathrm{a}$ & $26.58 \pm 5.66 \mathrm{~b}$ \\
$\mathbf{P O}_{4}{ }^{3-}$ & $0.96 \pm 0.59 \mathrm{c}$ & $1.38 \pm 0.84 \mathrm{c}$ & $28.33 \pm 1.27 \mathrm{~b}$ & $34.90 \pm 1.99 \mathrm{a}$ & $2.58 \pm 0.27 \mathrm{c}$ \\
$\mathbf{C l}^{-}$ & $176.01 \pm 62.80 \mathrm{~b}$ & $205.29 \pm 51.11 \mathrm{~b}$ & $235.87 \pm 14.01 \mathrm{~b}$ & $377.89 \pm 111.22 \mathrm{a}$ & $290.48 \pm 40.48 \mathrm{ab}$ \\
$\mathbf{S O}_{4}{ }^{2-}$ & $3138.23 \pm 212.15 \mathrm{a}$ & $1247.86 \pm 85.86 \mathrm{~b}$ & $1523.92 \pm 384.63 \mathrm{~b}$ & $1307.36 \pm 387.40 \mathrm{~b}$ & $7.14 \pm 3.95 \mathrm{c}$ \\
$\mathbf{K}^{+}$ & $7.21 \pm 5.64 \mathrm{~b}$ & $5.53 \pm 1.92 \mathrm{bc}$ & $17.01 \pm 3.25 \mathrm{a}$ & $23.06 \pm 3.53 \mathrm{a}$ & $0.35 \pm 0.08 \mathrm{c}$ \\
$\mathbf{N a}^{+}$ & $2540.57 \pm 33.67 \mathrm{a}$ & $1128.47 \pm 124.09 \mathrm{~b}$ & $898.83 \pm 176.23 \mathrm{c}$ & $849.20 \pm 112.12 \mathrm{c}$ & $175.63 \pm 1.20 \mathrm{~d}$ \\
$\mathbf{C a}^{2+}$ & $6.41 \pm 1.13 \mathrm{~d}$ & $7.24 \pm 0.30 \mathrm{~d}$ & $25.83 \pm 2.78 \mathrm{~b}$ & $14.66 \pm 4.60 \mathrm{c}$ & $49.00 \pm 3.90 \mathrm{a}$ \\
$\mathbf{M g}^{2+}$ & $31.86 \pm 4.08 \mathrm{a}$ & $24.20 \pm 2.71 \mathrm{~b}$ & $22.80 \pm 1.35 \mathrm{~b}$ & $20.54 \pm 4.17 \mathrm{bc}$ & $15.55 \pm 1.35 \mathrm{~d}$ \\
\hline
\end{tabular}

$\mathrm{W}_{9.0}$ is pure wastewater, EC $9.0 \mathrm{dS} \mathrm{m}^{-1}, \mathrm{~W}_{4.5}$ is diluted wastewater, EC $4.5 \mathrm{dS} \mathrm{m}^{-1}, \mathrm{DW}_{4.5}$ is depurated wastewater, EC $4.5 \mathrm{dS} \mathrm{m}^{-1}, \mathrm{PW}_{4.5}$ is phytodepurated wastewater, EC $4.5 \mathrm{dS} \mathrm{m}^{-1}$ and T is tap water, the control, EC $1.5 \mathrm{dS} \mathrm{m} \mathrm{m}^{-1}$. The values are the means \pm standard deviation in each treatment throughout the experiment. In each row, the same letter $(\mathrm{a}-\mathrm{d})$ indicates no significant differences among treatments at the $p<0.05$ level based on the LSD test.

The nitrate concentration in all the fertigation solutions tested ranged from 26.58 to $96.73 \mathrm{mg} \mathrm{L}^{-1}$. The phosphate concentration was very low in the treatments with pure and diluted wastewater, as well as in the control treatment $(\mathrm{T})$, while the depurated and phytodepurated treatments showed intermediate levels. Pure wastewater, the most saline treatment, did not have the highest $\mathrm{Cl}^{-}$ concentration, but it showed a high concentration of $\mathrm{SO}_{4}{ }^{2-}$, which was double that of all the treatments with an EC of $4.5 \mathrm{dS} \mathrm{m}^{-1}$, decreasing markedly under phytodepuration. The chloride concentration increased in diluted wastewater because it was higher in tap water than in pure wastewater (1.65-fold). The greatest $\mathrm{K}^{+}$concentrations were detected in $\mathrm{DW}_{4.5}$ and $\mathrm{PW}_{4.5}$. Sodium and $\mathrm{Mg}^{2+}$ concentrations were high in $W_{9.0}$, declining with dilution and with depuration, especially with phytodepuration. The calcium concentration was high in the control.

\subsection{Substrate Solution Composition}

Table 2 shows $\mathrm{pH}, \mathrm{EC}$, and the anion concentration in the substrate solution at the end of the trial. The highest value of $\mathrm{pH}$ was observed in $\mathrm{W}_{9.0}$, decreasing gradually in the following treatments, while the lowest value occurred in $\mathrm{PW}_{4.5}$ and $\mathrm{T}$. The highest level of EC was detected in $\mathrm{W}_{9.0}$, and the lowest in $\mathrm{T}$, following the same pattern as the fertigation solution EC.

The highest $\mathrm{NO}_{3}{ }^{-}$concentration was found in the treatment with pure wastewater $\left(74.26 \mathrm{mg} \mathrm{L}^{-1}\right)$, followed by the treatment with diluted wastewater $\left(51.60 \mathrm{mg} \mathrm{L}^{-1}\right)$; both treatments had the lowest $\mathrm{NO}_{3}{ }^{-}$concentration in the nutrient solution (28.14 and $31.19 \mathrm{mg} \mathrm{L}^{-1}$, respectively). Regarding the $\mathrm{PO}_{4}{ }^{3-}$ concentration, there were no significant differences between the treatments with pure wastewater (35.82 $\mathrm{mg} \mathrm{L}^{-1}$ ) and phytodepurated wastewater $\left(40.50 \mathrm{mg} \mathrm{L}^{-1}\right.$ ); however, this was double the concentration found in tap water. The highest $\mathrm{Cl}^{-}$concentrations were found in the treatments with diluted wastewater, depurated wastewater, phytodepurated wastewater, and tap water (808.25, $851.11,832.04$, and $831.41 \mathrm{mg} \mathrm{L}^{-1}$, respectively), but there were no significant differences between pure and diluted wastewater. The highest $\mathrm{SO}_{4}{ }^{2-}$ concentration values were found in the treatment with pure wastewater $\left(2521.63 \mathrm{mg} \mathrm{L}^{-1}\right)$, this being 3.27-fold greater than the concentration in tap water. 
Table 2. $\mathrm{pH}, \mathrm{EC}\left(\mathrm{dS} \mathrm{m}^{-1}\right)$, and ion concentration in the substrate solution $\left(\mathrm{mg} \mathrm{L}^{-1}\right)$.

\begin{tabular}{cccccc}
\hline Treatment & $\mathbf{W}_{\mathbf{9 . 0}}$ & $\mathbf{W}_{\mathbf{4 . 5}}$ & $\mathbf{D W}_{\mathbf{4 . 5}}$ & $\mathbf{P W}_{\mathbf{4 . 5}}$ & $\mathbf{T}$ \\
\hline $\mathbf{p H}$ & $7.26 \pm 0.01 \mathrm{a}$ & $7.16 \pm 0.09 \mathrm{ab}$ & $7.10 \pm 0.04 \mathrm{ab}$ & $7.06 \pm 0.06 \mathrm{~b}$ & $7.03 \pm 0.26 \mathrm{~b}$ \\
$\mathbf{E C}$ & $6.52 \pm 0.29 \mathrm{a}$ & $4.63 \pm 0.17 \mathrm{~b}$ & $4.41 \pm 0.64 \mathrm{~b}$ & $4.43 \pm 0.92 \mathrm{~b}$ & $2.07 \pm 0.07 \mathrm{c}$ \\
$\mathbf{N O}{ }^{-}$ & $74.26 \pm 9.34 \mathrm{a}$ & $51.60 \pm 13.03 \mathrm{~b}$ & $21.10 \pm 8.77 \mathrm{~d}$ & $31.50 \pm 4.75 \mathrm{c}$ & $18.76 \pm 3.30 \mathrm{~d}$ \\
$\mathbf{P O}_{4}{ }^{3-}$ & $35.82 \pm 6.35 \mathrm{ab}$ & $26.72 \pm 3.87 \mathrm{bc}$ & $24.90 \pm 5.96 \mathrm{c}$ & $40.50 \pm 2.23 \mathrm{a}$ & $17.16 \pm 1.17 \mathrm{c}$ \\
$\mathbf{C l}^{-}$ & $765.95 \pm 26.66 \mathrm{~b}$ & $808.25 \pm 13.12 \mathrm{ab}$ & $851.11 \pm 43.25 \mathrm{a}$ & $832.04 \pm 47.02 \mathrm{a}$ & $831.41 \pm 16.18 \mathrm{a}$ \\
$\mathbf{S O}_{4}{ }^{2-}$ & $2521.63 \pm 288.56 \mathrm{a}$ & $1614.21 \pm 84.85 \mathrm{~b}$ & $1661.26 \pm 197.91 \mathrm{~b}$ & $1453.37 \pm 236.67 \mathrm{~b}$ & $770.67 \pm 166.36 \mathrm{c}$ \\
$\mathbf{K}^{+}$ & $55.71 \pm 1.16 \mathrm{~ns}$ & $53.27 \pm 8.52 \mathrm{~ns}$ & $52.49 \pm 6.65 \mathrm{~ns}$ & $54.37 \pm 8.31 \mathrm{~ns}$ & $46.68 \mathrm{~ns}$ \\
$\mathbf{N a}^{+}$ & $1269.68 \pm 81.83 \mathrm{a}$ & $766.25 \pm 14.60 \mathrm{~b}$ & $761.83 \pm 48.44 \mathrm{~b}$ & $777.98 \pm 21.79 \mathrm{~b}$ & $238.77 \pm 25.66 \mathrm{c}$ \\
$\mathbf{C a}^{2+}$ & $62.48 \pm 4.05 \mathrm{~b}$ & $66.61 \pm 8.15 \mathrm{~b}$ & $71.99 \pm 13.36 \mathrm{~b}$ & $62.49 \pm 7.55 \mathrm{~b}$ & $96.85 \pm 5.30 \mathrm{a}$ \\
$\mathbf{M g}^{2+}$ & $17.69 \pm 1.23 \mathrm{~b}$ & $17.59 \pm 2.11 \mathrm{~b}$ & $18.38 \pm 3.00 \mathrm{~b}$ & $16.05 \pm 2.49 \mathrm{~b}$ & $22.23 \pm 1.50 \mathrm{a}$ \\
\hline
\end{tabular}

$\mathrm{W}_{9.0}$ is pure wastewater, EC $9.0 \mathrm{dS} \mathrm{m}^{-1}, \mathrm{~W}_{4.5}$ is diluted wastewater, EC $4.5 \mathrm{dS} \mathrm{m}^{-1}, \mathrm{DW}_{4.5}$ is depurated wastewater, EC $4.5 \mathrm{dS} \mathrm{m}^{-1}, \mathrm{PW}_{4.5}$ is phytodepurated wastewater, EC $4.5 \mathrm{dS} \mathrm{m}^{-1}$ and T is tap water, the control, EC $1.5 \mathrm{dS} \mathrm{m}^{-1}$. Data are the means \pm standard deviation of 4 samples per treatment at the end of the trial. In a row, the same letter $(\mathrm{a}-\mathrm{d})$ indicates no significant differences among treatments at the $p<0.05$ level based on the LSD test. ns indicates non-statistical differences.

Concerning the $\mathrm{K}^{+}$concentration in the substrate solution, there were no significant differences among treatments, with values from 46.68 to $55.71 \mathrm{mg} \mathrm{L}^{-1}$ in $\mathrm{T}$ and $\mathrm{W}_{9.0}$, respectively. The sodium concentration was significantly higher in $\mathrm{W}_{9.0}$, and it was approximately 1.65 and 5.31-fold greater with respect to the treatments with $4.5 \mathrm{dS} \mathrm{m}^{-1}$ and the control, respectively. The highest $\mathrm{Ca}^{2+}$ and $\mathrm{Mg}^{2+}$ concentrations were detected in the substrate irrigated with tap water, with values near to 1.45 and 1.30-fold greater, respectively, when compared with the rest of the treatments.

\subsection{Plant Biometric Parameters}

Fertigation with pure wastewater had a significant negative effect on plant FW (Table 3), affecting all plant organs, especially root FW, which represented only $4.73 \%$ of total $\mathrm{FW}$, in contrast to $25.37 \%, 22.72 \%$, $26.53 \%$, and $33.22 \%$ in the treatments with diluted wastewater, depurated wastewater, phytodepurated wastewater, and tap water, respectively. Considering both total FW and the FW of each organ, when phytodepurated water was used these parameters were significantly higher; with this treatment, root FW, shoot FW, flower FW, and total FW were 14.18-fold, 1.72-fold, 2.71-fold, and 2.53-fold greater, respectively, compared to pure wastewater. Shoot FW was significantly higher when plants were irrigated with phytodepurated water rather than tap water.

Table 3. Root, shoot, flower, and total fresh weight (FW) (g).

\begin{tabular}{cccccc}
\hline Treatments & $\mathbf{W}_{\mathbf{9 . 0}}$ & $\mathbf{W}_{\mathbf{4 . 5}}$ & $\mathbf{D W}_{\mathbf{4 . 5}}$ & $\mathbf{P W}_{\mathbf{4 . 5}}$ & $\mathbf{T}$ \\
\hline Roots FW & $0.21 \pm 0.04 \mathrm{c}$ & $2.42 \pm 0.62 \mathrm{~b}$ & $2.69 \pm 0.42 \mathrm{~b}$ & $2.94 \pm 1.22 \mathrm{ab}$ & $3.56 \pm 0.20 \mathrm{a}$ \\
Shoots FW & $3.45 \pm 0.46 \mathrm{c}$ & $4.95 \pm 0.52 \mathrm{~b}$ & $6.45 \pm 0.36 \mathrm{a}$ & $5.94 \pm 0.38 \mathrm{a}$ & $5.18 \pm 0.3 \mathrm{~b}$ \\
Flowers FW & $0.81 \pm 0.25 \mathrm{c}$ & $2.62 \pm 0.47 \mathrm{a}$ & $2.68 \pm 0.37 \mathrm{a}$ & $2.19 \pm 0.47 \mathrm{ab}$ & $1.97 \pm 0.37 \mathrm{~b}$ \\
Total FW & $4.36 \pm 0.76 \mathrm{~d}$ & $9.55 \pm 0.19 \mathrm{c}$ & $11.82 \pm 0.49 \mathrm{a}$ & $11.07 \pm 0.53 \mathrm{ab}$ & $10.71 \pm 0.69 \mathrm{bc}$ \\
\hline
\end{tabular}

$\mathrm{W}_{9.0}$ is pure wastewater, $\mathrm{EC} 9.0 \mathrm{dS} \mathrm{m}^{-1}, \mathrm{~W}_{4.5}$ is diluted wastewater, $\mathrm{EC} 4.5 \mathrm{dS} \mathrm{m}^{-1}, \mathrm{DW}_{4.5}$ is depurated wastewater, EC $4.5 \mathrm{dS} \mathrm{m}^{-1}, \mathrm{PW}_{4.5}$ is phytodepurated wastewater, EC $4.5 \mathrm{dS} \mathrm{m}^{-1}$ and T is tap water, the control, EC $1.5 \mathrm{dS} \mathrm{m}^{-1}$. Data are the means \pm standard deviation of 4 samples per treatment at the end of the trial. In a row, the same letter (a-d) indicates no significant differences among treatments at the $p<0.05$ level based on the LSD test.

Plant height was significantly higher and the plants showed greater width and number of leaves (Table 4) when they were irrigated with depurated (12.89 cm-high, $10.86 \mathrm{~cm}$-width, and 77 leaves per plant) and phytodepurated wastewater $(12.58 \mathrm{~cm}$-high, $11.27 \mathrm{~cm}$-width, and 75 leaves per plant), showing no significant differences with respect to those irrigated with tap water $(13.31 \mathrm{~cm}-\mathrm{high}$, $10.74 \mathrm{~cm}$-width, and 64.38 leaves per plant). 
Table 4. Plant height $(\mathrm{cm})$, plant width $(\mathrm{cm})$, number of leaves, number of flowers, leaf area $\left(\mathrm{cm}^{2}\right)$, and water content (WC) on a fresh weight (FW) basis (\%).

\begin{tabular}{cccccc}
\hline Treatments & $\mathbf{W}_{\mathbf{9 . 0}}$ & $\mathbf{W}_{\mathbf{4 . 5}}$ & $\mathbf{D W}_{4.5}$ & $\mathbf{P W}_{4.5}$ & $\mathbf{T}$ \\
\hline Height & $10.79 \pm 1.22 \mathrm{c}$ & $11.98 \pm 1.49 \mathrm{~b}$ & $12.89 \pm 1.54 \mathrm{a}$ & $12.58 \pm 1.44 \mathrm{ab}$ & $13.31 \pm 1.67 \mathrm{a}$ \\
$\quad \begin{array}{l}\text { Width } \\
\text { Number of }\end{array}$ & $9.40 \pm 1.30 \mathrm{c}$ & $10.13 \pm 0.98 \mathrm{~b}$ & $10.86 \pm 1.00 \mathrm{a}$ & $11.27 \pm 1.64 \mathrm{a}$ & $10.74 \pm 0.86 \mathrm{ab}$ \\
$\quad$ leaves & $59.38 \pm 10.02 \mathrm{~b}$ & $55.88 \pm 4.25 \mathrm{~b}$ & $77.00 \pm 6.10 \mathrm{a}$ & $75.00 \pm 11.38 \mathrm{a}$ & $64.38 \pm 9.00 \mathrm{ab}$ \\
$\begin{array}{c}\text { Number of } \\
\text { flowers }\end{array}$ & $9.46 \pm 3.93 \mathrm{~b}$ & $14.17 \pm 7.60 \mathrm{a}$ & $15.63 \pm 6.86 \mathrm{a}$ & $16.42 \pm 7.68 \mathrm{a}$ & $13.46 \pm 7.99 \mathrm{a}$ \\
Leaf area & $606.38 \pm 78.81 \mathrm{c}$ & $912.50 \pm 145.04 \mathrm{~b}$ & $1174.00 \pm 161.23 \mathrm{a}$ & $589.88 \pm 96.63 \mathrm{c}$ & $908.50 \pm 145.74 \mathrm{~b}$ \\
$\quad$ WC & $82.15 \pm 0.38 \mathrm{~b}$ & $84.18 \pm 0.69 \mathrm{a}$ & $83.43 \pm 0.37 \mathrm{a}$ & $84.06 \pm 0.28 \mathrm{a}$ & $84.07 \pm 0.88 \mathrm{a}$ \\
\hline
\end{tabular}

$\mathrm{W}_{9.0}$ is pure wastewater, EC $9.0 \mathrm{dS} \mathrm{m}^{-1}, \mathrm{~W}_{4.5}$ is diluted wastewater, EC $4.5 \mathrm{dS} \mathrm{m}^{-1}, \mathrm{DW}_{4.5}$ is depurated wastewater, EC $4.5 \mathrm{dS} \mathrm{m}^{-1}, \mathrm{PW}_{4.5}$ is phytodepurated wastewater, EC $4.5 \mathrm{dS} \mathrm{m}^{-1}$ and T is tap water, the control, EC $1.5 \mathrm{dS} \mathrm{m}^{-1}$. Data are the means \pm standard deviation of 4 samples per treatment at the end of the trial. In a row, the same letter $(\mathrm{a}-\mathrm{c})$ indicates no significant differences among treatments at the $p<0.05$ level based on the LSD test.

As far as the number of flowers per plant was concerned, it increased when the wastewater was treated either by dilution, depuration, or phytodepuration, with 14.17, 15.63, and 16.42 leaves, respectively, showing no significant differences with respect to tap water.

The leaf area reached its highest values when the plants were irrigated with depurated water $\left(1174.00 \mathrm{~cm}^{2}\right)$, and its lowest with pure wastewater and phytodepurated wastewater $(606.38$ and $589.88 \mathrm{~cm}^{2}$, respectively).

The water content on an FW basis was the lowest in the treatment with pure wastewater $(82.15 \%)$, with no significant differences among the other treatments.

\subsection{Nutrients Extraction}

Plants irrigated with depurated wastewater and phytodepurated wastewater extracted more $\mathrm{N}$ (58.83 and $61.20 \mathrm{~g}$, respectively), $\mathrm{P}$ (13.69 and $13.05 \mathrm{~g}$, respectively) and $\mathrm{Cl}$ (49.09 and $54.81 \mathrm{~g}$, respectively) than the plants tested with the other treatments (Table 5). Pure wastewater led to the lowest N, P, and $\mathrm{Cl}$ content in plants, although the differences in $\mathrm{P}$ and $\mathrm{Cl}$ content among $\mathrm{W}_{9.0}, \mathrm{~W}_{4.5}$, and $\mathrm{T}$ were not significant. As far as $\mathrm{S}$ extraction is concerned, it showed the greatest value when plants were subjected to the $W_{9.0}$ treatment, being 2.77 -fold greater with respect to the control treatment, while the $\mathrm{S}$ content reached intermediate values with the phytodepurated wastewater.

Table 5. Nutrients extraction $(\mathrm{mg})$ in pansy at the end of the trial.

\begin{tabular}{cccccc}
\hline Treatments & $\mathbf{W}_{\mathbf{9 . 0}}$ & $\mathbf{W}_{\mathbf{4 . 5}}$ & $\mathbf{D W}_{\mathbf{4 . 5}}$ & $\mathbf{P W}_{\mathbf{4 . 5}}$ & $\mathbf{T}$ \\
\hline $\mathbf{N}$ & $33.10 \pm 4.92 \mathrm{c}$ & $47.60 \pm 5.10 \mathrm{~b}$ & $58.83 \pm 3.40 \mathrm{a}$ & $61.20 \pm 5.79 \mathrm{a}$ & $51.61 \pm 1.89 \mathrm{~b}$ \\
$\mathbf{P}$ & $9.03 \pm 0.39 \mathrm{~b}$ & $10.33 \pm 1.74 \mathrm{~b}$ & $13.69 \pm 0.95 \mathrm{a}$ & $13.05 \pm 1.05 \mathrm{a}$ & $10.53 \pm 1.63 \mathrm{~b}$ \\
$\mathbf{C l}$ & $29.13 \pm 2.06 \mathrm{c}$ & $35.54 \pm 12.00 \mathrm{bc}$ & $49.09 \pm 3.86 \mathrm{ab}$ & $54.81 \pm 7.18 \mathrm{a}$ & $41.45 \pm 4.71 \mathrm{bc}$ \\
$\mathbf{S}$ & $19.64 \pm 1.87 \mathrm{a}$ & $7.98 \pm 2.55 \mathrm{c}$ & $8.76 \pm 3.01 \mathrm{c}$ & $11.78 \pm 1.01 \mathrm{~b}$ & $7.08 \pm 0.69 \mathrm{c}$ \\
$\mathbf{K}$ & $27.07 \pm 1.52 \mathrm{~b}$ & $39.03 \pm 9.38 \mathrm{a}$ & $41.32 \pm 2.32 \mathrm{a}$ & $47.60 \pm 5.31 \mathrm{a}$ & $43.44 \pm 5.33 \mathrm{a}$ \\
$\mathbf{N a}$ & $33.62 \pm 0.31 \mathrm{a}$ & $36.86 \pm 1.40 \mathrm{a}$ & $34.35 \pm 0.70 \mathrm{a}$ & $37.70 \pm 0.53 \mathrm{a}$ & $14.28 \pm 0.54 \mathrm{~b}$ \\
$\mathbf{C a}$ & $9.55 \pm 1.34 \mathrm{~cd}$ & $11.75 \pm 1.40 \mathrm{bc}$ & $12.58 \pm 5.45 \mathrm{~b}$ & $9.34 \pm 5.00 \mathrm{~d}$ & $15.46 \pm 1.00 \mathrm{a}$ \\
$\mathbf{M g}$ & $2.93 \pm 1.62 \mathrm{~b}$ & $4.78 \pm 1.42 \mathrm{a}$ & $5.16 \pm 1.16 \mathrm{a}$ & $4.04 \pm 0.26 \mathrm{ab}$ & $4.88 \pm 1.67 \mathrm{a}$ \\
\hline
\end{tabular}

$\mathrm{W}_{9.0}$ is pure wastewater, $\mathrm{EC} 9.0 \mathrm{dS} \mathrm{m}^{-1}, \mathrm{~W}_{4.5}$ is diluted wastewater, $\mathrm{EC} 4.5 \mathrm{dS} \mathrm{m}^{-1}, \mathrm{DW}_{4.5}$ is depurated wastewater, EC $4.5 \mathrm{dS} \mathrm{m}^{-1}, \mathrm{PW}_{4.5}$ is phytodepurated wastewater, EC $4.5 \mathrm{dS} \mathrm{m}^{-1}$ and T is tap water, the control, EC $1.5 \mathrm{dS} \mathrm{m}^{-1}$. Data are the means \pm standard deviation of 4 samples per treatment at the end of the trial. In a row, the same letter (a-d) indicates no significant differences among treatments at the $p<0.05$ level based on the LSD test.

Potassium content in pansy was the lowest with pure wastewater $(27.07 \mathrm{~g})$, while the Na content showed the lowest values with tap water $(14.28 \mathrm{~g})$. Calcium extraction was higher in the plants irrigated with tap water $(15.46 \mathrm{~g})$. Magnesium extraction was lower with pure wastewater $(2.93 \mathrm{~g})$ and phytodepurated wastewater ( $4.04 \mathrm{~g})$; nevertheless, there were no significant differences between the control and the treatments irrigated with $4.5 \mathrm{dS} \mathrm{m}^{-1}$. 


\section{Discussion}

\subsection{Fertigation Solution Assessment}

The nutrient solution $\mathrm{pH}$ was basic, being above the values recommended for bedding plants (5.5-6.5) [19], as well as EC levels in the treatments with pure, diluted, depurated and phytodepurated wastewater, as the optimum EC range for bedding plants is $1.5-2.0 \mathrm{dS} \mathrm{m}^{-1}$ [19]. Nitrate, $\mathrm{PO}_{4}{ }^{3-}, \mathrm{K}^{+}, \mathrm{Ca}^{2+}$, and $\mathrm{Mg}^{2+}$ concentrations in all the fertigation solutions tested were below the values recommended for bedding plants $\left(398.66,50.44,116.61,99.80\right.$, and $23.76 \mathrm{mg} \mathrm{L}^{-1}$, respectively), while $\mathrm{SO}_{4}{ }^{2-}, \mathrm{Cl}^{-}$, and $\mathrm{Na}^{+}$ concentrations surpassed the optimal levels (113.76, 10.99, and $\left.3.01 \mathrm{mg} \mathrm{L}^{-1}\right)$ [19].

In this trial, we evaluated if MSW leachates can be used as a potential source for fertilizers. According to the EU legislation [20], to be considered a liquid organo-mineral fertilizer, a product must contain at least one of the following declared nutrients in the minimum quantities: $2.00 \%$ by weight of total $\mathrm{N}$, of which $0.50 \%$ by mass of the fertilizer product must be organic $\mathrm{N}, 2.00 \%$ by weight of total $\mathrm{P}_{2} \mathrm{O}_{5} ; 2.00 \%$ by mass of total $\mathrm{K}_{2} \mathrm{O}$. Pure wastewater contained an average concentration of $28.15 \mathrm{mg}$ of $\mathrm{NO}_{3}{ }^{-} \mathrm{L}^{-1}, 0.96 \mathrm{mg}$ of $\mathrm{PO}_{4}{ }^{3-}$ and $4.21 \mathrm{mg}$ of $\mathrm{K}^{+} \mathrm{L}^{-1}$, which means $0.64 \% \mathrm{~N}, 0.07 \% \mathrm{P}_{2} \mathrm{O}_{5}$, and $0.87 \%$ $\mathrm{K}_{2} \mathrm{O}$. These values do not adhere to the requirements stated in the legislation. As the addition of fertilizers was needed to prevent the plants cultivated in the phytodepuration station from suffering nutrient deficiencies, these concentrations were higher in the phytodepurated wastewater $(2.18 \% \mathrm{~N}$, $2.61 \% \mathrm{P}_{2} \mathrm{O}_{5}$, and $\left.2.78 \% \mathrm{~K}_{2} \mathrm{O}\right)$ and in the depurated wastewater $\left(2.18 \% \mathrm{~N}, 2.12 \% \mathrm{P}_{2} \mathrm{O}_{5}\right.$, and $\left.2.05 \% \mathrm{~K}_{2} \mathrm{O}\right)$, where fertilizers were also applied, adhering to the mentioned requirements for all the nutrients.

In the treatments with pure and diluted wastewater, as well as with tap water, $\mathrm{NO}_{3}{ }^{-}$concentrations did not exceed $50 \mathrm{mg} \mathrm{L}^{-1}$, the maximum concentration established in the Nitrates Directive (91/676/EEC) and the Drinking Water Directive (98/83/EC), but in the depurated or phytodepurated treatments, they were higher because of the fertilizers applied.

Declining concentrations of orthophosphate associated with industrial and urban wastewater pollution can be observed in most of Europe's surface waters [21], which agrees with the levels found in the treatments with pure and diluted wastewater.

\subsection{Biometric Parameters}

Fertigation with pure wastewater, in which the $\mathrm{SO}_{4}{ }^{2-}$ concentration was extremely high, negatively affected the pansy plants FW (especially root FW), plant height and width, number of leaves, number of flowers, leaf area and WC (on an FW basis). Root growth appears to be limited by increasing $\mathrm{Na}^{+}$concentrations in the growth medium [22]. Moreover, in Brassica rapa cv. Komatsuna (Van der Wal, Hoogeveen, The Netherlands), $\mathrm{Na}_{2} \mathrm{SO}_{4}$, and $\mathrm{K}_{2} \mathrm{SO}_{4}$ reduced plant growth more than $\mathrm{NaCl}$ [23]. Exposure of Allium cepa L. to a $100 \mathrm{mM} \mathrm{Na}_{2} \mathrm{SO}_{4}$ salinity reduced plant biomass by 55\% [24] and reductions in growth parameters (plant height, number of green leaves in the main stem and DW) of Hordeum vulgare L. were obtained when the salt concentration was raised to 6000 ppm [25].

It has been proven that Lactuca sativa L. leaf expansion is sensitive to $\mathrm{Na}_{2} \mathrm{SO}_{4}$ through a combined suppression of leaf expansion and the rate of production of new leaves [26]; the reduction in leaf area might be due to inhibition of cell division and cell expansion under salt stress [27]. A decrease in leaf size under unfavorable conditions allows the conservation of energy [28].

Leaf necrosis appeared in lettuce at $\mathrm{Na}_{2} \mathrm{SO}_{4}$ concentrations above $40 \mathrm{mM}$, and this can be related to the accumulation of $\mathrm{Na}^{+}$[26], which was also very high in the aerial vegetative fraction of pansy plants fertigated with wastewaters, meaning that water, ions, and photoassimilates had less chance to move through the plant [29]. Several authors state that reductions in growth might be due to a disturbance of membrane integrity and function, interference with the internal balance of solutes and the uptake of other nutrients, as well as toxicity for several cellular processes [22,30,31]. For example, an excessive accumulation of $\mathrm{Na}^{+}$decreases stomatal conductance and the photosynthetic rate [26], and $\mathrm{Na}_{2} \mathrm{SO}_{4}$ produces photochemical stress [23]. Besides, the growth reduction of lettuce under $\mathrm{Na}_{2} \mathrm{SO}_{4}$ stress may 
be due to the combined effects of osmotic stress and excess accumulation of $\mathrm{Na}^{+}$. The decrease in water uptake per plant implies osmotic stress under $\mathrm{Na}_{2} \mathrm{SO}_{4}$ salinity [26].

On the other hand, the higher toxicity of $\mathrm{Na}_{2} \mathrm{SO}_{4}$ over $\mathrm{NaCl}[23,32]$ might be due to less effective sequestration or mobility of $\mathrm{Na}^{+}$towards some innocuous centers of plant tissues [33]. Sodium sulfate causes growth inhibition and toxicity in Prosopis strombulifera (Lam.) Benth. plants because when $\mathrm{SO}_{4}{ }^{2-}$ is present in the medium, the capacities for ion compartmentalization and osmotic adjustment are reduced, resulting in a water imbalance and symptoms of toxicity due to altered carbon metabolism, e.g., synthesis of sorbitol instead of mannitol, reduced sucrose production and protein content [34]. In Medicago sativa L. plants, the yield declines are probably due to anyone or a combination of low water potential, toxic shoot $\mathrm{Cl}^{-}$and possibly $\mathrm{SO}_{4}{ }^{2-}$, and deficiencies of shoot $\mathrm{P}$ and organic anions [35].

Wastewater quality was greatly improved by depuration and phytodepuration, reducing the $\mathrm{SO}_{4}{ }^{2-}$ concentration by half and $\mathrm{Na}^{+}$by two-thirds, which caused an increase in shoots, flowers, and total FW. Plant height and width, number of leaves and number of flowers, and water content also ameliorated under these treatments, with values similar to the values obtained with tap water irrigation, where these toxic ions were at very low concentrations.

\subsection{Nutritional Parameters}

\subsubsection{Nitrogen}

In constructed wetlands (CWs), organic $\mathrm{N}$ undergoes a series of transformations which are related to their mechanisms of abatement. The first stage would be ammonification, which transforms organic $\mathrm{N}$ into $\mathrm{NH}_{4}{ }^{+}-\mathrm{N}$. In a second stage, $\mathrm{NH}_{4}{ }^{+}-\mathrm{N}$ is converted by bacteria into $\mathrm{NO}_{2}{ }^{-}-\mathrm{N}$ and $\mathrm{NO}_{3}{ }^{-}-\mathrm{N}$ in the presence of oxygen. The interconversions between different forms of total $\mathrm{N}$ are associated with abatement mechanisms such as assimilation by plants, volatilization of gaseous forms, and adsorption by cation exchange [36]. On the other hand, there can be an effect on $\mathrm{N}$ removal subject to microbial activities [37].

In this assay, there was an average $\mathrm{NO}_{3}{ }^{-}$concentration of $28.14 \mathrm{mg} \mathrm{L}^{-1}$ in pure wastewater, which increased in phytodepurated wastewater (3-fold), but also in depurated water, due to the fertilizers applied to the lysimeters located in the phytodepuration station. In a study carried out in Alexandria, Egypt [38], the average $\mathrm{NO}_{3}{ }^{-}$concentration in landfill leachate was low, ranging from 0.36 to $2.90 \mathrm{mg} \mathrm{L}^{-1}$. Prevalent reducing conditions in a landfill may cause a reduction of $\mathrm{NO}_{3}^{-}$to $\mathrm{NH}_{4}{ }^{+}$or to $\mathrm{N}_{2}$, which results in a decrease in nitrate values and an increase in ammonia concentrations [39].

Considering the $\mathrm{NO}_{3}{ }^{-}$concentration in the soil solution of the treatments with landfill leachate, this was very low in $\mathrm{DW}_{4.5}$ and $\mathrm{PW}_{4.5}$, due to the higher extraction by the aforementioned treatments, being 2-fold greater with respect to that observed in the treatment with pure wastewater.

An application of $\mathrm{S}$ in the absence of $\mathrm{N}$ decreased the $\mathrm{N}$ concentration in mustard plants, but when $\mathrm{N}$ was added, the effect was synergistic [40]. In this assay, both $\mathrm{NO}_{3}{ }^{-}$and $\mathrm{SO}_{4}{ }^{2-}$ in the substrate solution reached their highest values in $\mathrm{W}_{9.0}$; however, $\mathrm{N}$ accumulation in plants was the lowest due to their lower biomass. Aghajanzadeh et al. [24] also reported that $\mathrm{Na}_{2} \mathrm{SO}_{4}$ salinity resulted in a strongly reduced $\mathrm{NO}_{3}{ }^{-}$content (by $9 \%$ and $43 \%$ at 50 and $100 \mathrm{mM}$, respectively) of the shoot of Allium cepa $\mathrm{L}$. plants, whereas that of the root remained unaffected.

\subsubsection{Phosphorous}

In CWs, the mineral components of the bed, sand, and gravel lead to adsorption and precipitation reactions of $\mathrm{P}$ with $\mathrm{Ca}, \mathrm{Al}$, and $\mathrm{Fe}$ ions [41]. However, the only sustainable mechanism for total $\mathrm{P}$ removal is plant uptake and subsequent harvesting. With Phragmites australis (Cav.) Trin. ex Steud ssp. altissima, the percentage abatement of total $P$ regarding influent wastewaters can exceed $80 \%$ [36].

In the present study, the $\mathrm{PO}_{4}{ }^{3-}$ concentration in pure wastewater was low but higher than the $0.37 \mathrm{mg} \mathrm{L}^{-1}$ detected by Abd El-Salam and Abu-Zuid [38]; $\mathrm{PO}_{4}{ }^{3-}$ decreased during the stabilization process and this may be attributed to the compaction of the wastes in the landfill. Phosphate concentration 
was very low in pure wastewater, but the fertilization applied in the phytodepuration station caused a considerable increase in this parameter.

In the treatment with pure wastewater, the $\mathrm{PO}_{4}{ }^{3-}$ concentration was much higher in the soil solution than in the fertigation solution. It has been demonstrated that there is distinctly increased availability of $\mathrm{H}_{2} \mathrm{PO}_{4}{ }^{-}$in peat soils when these come into contact with water with even moderately increased $\mathrm{SO}_{4}{ }^{2-}$ or $\mathrm{Cl}^{-}$levels [42]. Furthermore, Zahoor et al. [43] observed that $\mathrm{SO}_{4}{ }^{2-}$ salt released greater amounts of labile $\mathrm{P}$ fractions from soil (salt and $\mathrm{NaHCO}_{3}$ extracted $\mathrm{P}$ ) than $\mathrm{Cl}^{-}$, and Ahmad et al. [44] suggested that synergetic effects exist between $\mathrm{Na}^{+}$and $\mathrm{SO}_{4}{ }^{2-}$ ions (pure wastewater contained extremely high concentrations of both ions) which enhanced the $\mathrm{P}$ release.

The phosphate concentration in the soil solution was also high in the treatment with phytodepurated water. It has been demonstrated that root exudates of Beta vulgaris L. contain salicylic acid and citramalic acid, metabolites that can solubilize soil P; their exudation by roots being stimulated by P deficiency [45]. Furthermore, Chen et al. [37] found Cerea Spore Bacilli with functions in $\mathrm{PO}_{4}{ }^{3-}$ dissolution in the rhizosphere of three sequenced cells in a vertical subsurface-flow wetland system constructed for municipal sewage treatment. The positive effect of root exudates and microbial activity in roots on $\mathrm{P}$ availability can lead to a higher content of $\mathrm{P}$ in plants fertigated with phytodepurated wastewaters, as occurs with Cordyline fruticosa (L.) A.Chev. 'Red Edge' plants fertigated with leachates from horticultural crops, compared with the saline control [46]; a similar effect was observed in this assay.

On the other hand, it must be taken into account that high concentrations of $\mathrm{SO}_{4}{ }^{2-}$ and $\mathrm{Cl}^{-}$ salts have effects on plants that depend on the species. In Brassica rapa L., shoot contents of $\mathrm{P}$ were decreased more strongly by exposure to $\mathrm{Na}_{2} \mathrm{SO}_{4}$ compared to $\mathrm{NaCl}$ [23], but in Medicago sativa $\mathrm{L}$. plants, $\mathrm{P}$ deficiency occurred despite a high $\mathrm{P}$ solution, due to $\mathrm{Cl}^{-}$or $\mathrm{SO}_{4}{ }^{2-}$ competition in saline environments [35]. Conversely, and agreeing with our results, in Coriandrum sativum L. plants, leaf $P$ was increased by $\mathrm{K}_{2} \mathrm{SO}_{4}+\mathrm{MgNO}_{3}$ with an EC of $4 \mathrm{dS} \mathrm{m}^{-1}$ [47], while P contents in Allium cepa L. remained unaffected by $\mathrm{NaCl}$ and $\mathrm{Na}_{2} \mathrm{SO}_{4}$ [24].

\subsubsection{Chlorine}

Full-scale hybrid CWs systems built for municipal wastewater treatment with Phragmites australis Cav. Trin. ex Steud., Typha latifolia L., Hydrocotyle umbellata L., and Canna indica L. had an efficiency percentage of $39.68 \%$ for $\mathrm{Cl}^{-}$, thanks to microbial activities and substrate-based wetland processes [48], while the efficiency reached $61 \%$ in a phytoremediation garden with Pistia stratiotes L., Eichhornia crassipes (Mart.) Solms., Hydrocotyle umbellata L., Lemna minor (L.) Griff., Typha latifolia L., and Scirpus acutus Muehl. ex Bigelow [49]. Nonetheless, in this assay the $\mathrm{Cl}^{-}$concentration was not very high in pure wastewater, being even lower than in the control, so phytodepuration did not cause a reduction in this parameter.

The average $\mathrm{Cl}^{-}$concentration in pure wastewater was $176.01 \mathrm{mg} \mathrm{L}^{-1}$, while Abd El-Salam and Abu-Zuid [38] detected values that ranged widely from 9500.00 to $16.25 \mathrm{mg} \mathrm{L}^{-1}$. The lowest average $\mathrm{Cl}^{-}$concentration in the fertigation solution $\left(176.01 \mathrm{mg} \mathrm{L}^{-1}\right)$ and the substrate solution $\left(765.95 \mathrm{mg} \mathrm{L}^{-1}\right)$ were detected in pure wastewater, and, for this reason, plant extraction was very low, compared with the other treatments; moreover, $\mathrm{SO}_{4}{ }^{2-}$ salinity affected root $\mathrm{FW}$ and growth, and, consequently, ion uptake. Nevertheless, the $\mathrm{Cl}^{-}$content of both root and shoot of Allium cepa L. was not affected by $\mathrm{SO}_{4}{ }^{2-}$ salinity [24].

However, with phytodepurated wastewater $\mathrm{Cl}$ extraction was the highest, which is related to the high concentration in the fertigation solution and the substrate solution, but no toxicity symptoms were observed; Villarino and Mattson [50] suggested that some bedding plant species can be grown in moderately saline fertigation solutions. Moreover, in Brassica rapa L. plants, the translocation of $\mathrm{Cl}$ to the shoot was more effectively restricted upon exposure to $\mathrm{NaCl}$ than the translocation of $\mathrm{SO}_{4}{ }^{2-}$ upon exposure to $\mathrm{Na}_{2} \mathrm{SO}_{4}$ [23]. 


\subsubsection{Sulfur}

The increase in the water EC in soils and waters at the bottom of abandoned municipal landfills is partly due to an enrichment in $\mathrm{Ca}^{2+}$ and $\mathrm{SO}_{4}{ }^{2-}$, probably originating from the leachates of plaster-made construction wastes [51]. Sulfate may be due to the decomposition of proteins [38].

In anaerobic $\mathrm{SO}_{4}{ }^{2-}$ reduction mechanisms, $\mathrm{SO}_{4}{ }^{2-}$ serves as an electron acceptor via $\mathrm{SO}_{4}{ }^{2-}$ reducing bacteria, whereas products of the fermentation process donate electrons with an end product of sulfide $\left(\mathrm{S}^{2-}\right)$. For example, Desulfovibrio bacteria utilize $\mathrm{SO}_{4}{ }^{2-}$ as the final electron acceptor, producing $\mathrm{H}_{2} \mathrm{~S}$ [52]. Sulfate reduction can contribute to substantial organic material removal in horizontal subsurface-flow $\mathrm{CWs}[53,54]$. However, increasing $\mathrm{SO}_{4}{ }^{2-}$ reduction can also inhibit $\mathrm{NH}_{4}-\mathrm{N}$ and $\mathrm{BOD}$ removal kinetics in horizontal flow wetlands [54], thereby diminishing treatment performances [52]. Several intermediates of the $\mathrm{S}$ reduction pathway are toxic $[55,56]$, but also $\mathrm{SO}_{4}{ }^{2-}$ was related to toxic effects on plant metabolism through inhibition of photophosphorylation [57].

In pure leachates, $\mathrm{SO}_{4}{ }^{2-}$ concentrations were very high, surpassing the values detected by Chofqi et al. (1150.00 $\left.\mathrm{mg} \mathrm{L}^{-1}\right)$ in leachates from landfills [58]. In a phytoremediation garden for the cyclic treatment of municipal wastewater, $\mathrm{SO}_{4}{ }^{2-}$ was slightly enhanced [49]. Conversely, in this assay, there was an average $\mathrm{SO}_{4}{ }^{-}$concentration of $3138.23 \mathrm{mg} \mathrm{L}^{-1}$ in pure wastewater, which decreased in phytodepurated wastewater by half $\left(1307.36 \mathrm{mg} \mathrm{L}^{-1}\right)$. This may be due to the uptake of the plants grown in the phytodepuration station. There is also a reduction in diluted and depurated wastewater, as a cause of its dilution with tap water, which showed the lowest values. The sulfate concentration in the soil solution of each treatment, as well as the total extraction, was directly related to its concentration in the fertigation solution, with the $\mathrm{SO}_{4}{ }^{2-}$ content being excessive in the plants treated with $\mathrm{W}_{9.0}$.

A promotion of $\mathrm{Na}^{+}$toxicity by $\mathrm{SO}_{4}{ }^{2-}$ could be caused by an increased uptake or accumulation of $\mathrm{Na}^{+}$. An imbalanced cation-anion uptake may also be expected, as the plasma membrane is less permeable for $\mathrm{SO}_{4}{ }^{2-}$ than for $\mathrm{Cl}^{-}$. The consequence may be a stronger negative effect on other cations, such as $\mathrm{K}^{+}$or $\mathrm{Ca}^{2+}$, which experience competition with $\mathrm{Na}^{+}$. The second explanation for the increased toxicity of $\mathrm{Na}_{2} \mathrm{SO}_{4}$ over $\mathrm{NaCl}$ is the higher toxicity of $\mathrm{SO}_{4}{ }^{2-}$ compared to $\mathrm{Cl}^{-}$, either caused by a higher accumulation or higher tissue toxicity of $\mathrm{SO}_{4}{ }^{2-}$ over $\mathrm{Cl}^{-}$. In this scenario, the additive toxicities of $\mathrm{Na}^{+}$ and $\mathrm{SO}_{4}{ }^{2-}$ would result in the toxicity of $\mathrm{Na}_{2} \mathrm{SO}_{4}$, rather than an interactive effect of $\mathrm{SO}_{4}{ }^{2-}$ with $\mathrm{Na}^{+}$[23].

\subsubsection{Sodium}

Alavi et al. [59] found concentrations of $15.00-382.00 \mathrm{ppm}$ of $\mathrm{Na}^{+}$in landfill leachates. The concentrations found in the pure wastewaters of this assay surpass these values, declining with dilution and with depuration and phytodepuration. In a hybrid CW, Ali et al. recorded a treatment efficiency percentage of 28.80 for $\mathrm{Na}^{+}$[48].

The sodium concentration in the substrate solution was lower than in the fertigation solution for all the treatments with wastewaters. The elevated concentration detected in $\mathrm{W}_{9.0}$ did not lead to greater $\mathrm{Na}^{+}$extraction by pansy plants. In other words, even though this treatment presented a greater $\mathrm{Na}^{+}$ concentration in the growth medium, the plants of the treatments with leachates absorbed equivalent amounts of $\mathrm{Na}^{+}$; nevertheless, it must be taken into account that growth was considerably reduced in $\mathrm{W}_{9.0}$, which indicates that the $\mathrm{Na}^{+}$concentration in plant tissues reached higher levels than in the other treatments tested. These results were in line with the findings reported by Lopes-Cruz et al. [60], who observed that the application of $60 \mathrm{mM} \mathrm{NaCl}$ to banana plants reduced root, stem, and leaf dry masses by $53.2 \%, 42.6 \%$, and $32.8 \%$, respectively, and it also reduced the transpiration rate by $44.4 \%$; however, salinity did not influence the amount of $\mathrm{Na}^{+}$uptaken.

\subsubsection{Potassium}

Potassium concentrations of 3.90-120.48 $\mathrm{mg} \mathrm{L}^{-1}$ have been detected in landfill leachates [59]. The concentrations found in the pure wastewaters used in this assay fit into this range. The higher 
values detected in the $\mathrm{DW}_{4.5}$ and $\mathrm{PW}_{4.5}$ treatments were due to the fertilizers applied in the phytodepuration station.

In spite of the fact that there were no significant differences in $\mathrm{K}^{+}$concentration among treatments in the substrate solutions, due to the nutrients existing in the substrate employed (Carmo et al. [61] detected values of $0.82 \mathrm{~g} \mathrm{~kg}^{-1}$ of $\mathrm{K}^{+}$in peat), $\mathrm{K}$ extraction was lowest in pansy plants irrigated with pure wastewater. Several authors state that excess $\mathrm{Na}^{+}$accumulation is highly deleterious to the plants, with effects including induction of cytosolic $\mathrm{K}^{+}$efflux and consequently an imbalance in cellular homeostasis, oxidative stress, interference with $\mathrm{Ca}^{2+}$ and $\mathrm{K}^{+}$functions, nutrient deficiency, retarded growth, and even the death of plant cells [62-65].

\subsubsection{Calcium}

Alavi et al. [59] found concentrations of 3.90-60.92 ppm of $\mathrm{Ca}^{2+}$ in the MSW leachates in Iranian metropolises. The concentrations found in the pure wastewaters in this assay fit into this range. The higher values detected in the $\mathrm{DW}_{4.5}$ and $\mathrm{PW}_{4.5}$ treatments are due to the fertilizers applied to the plants in the phytodepuration station.

There were no significant differences in the $\mathrm{Ca}^{2+}$ concentration in the substrate solutions among the treatments with landfill leachate due to the nutrients existing in the substrate employed, as values of $0.60 \mathrm{~g} \mathrm{~kg}^{-1}$ of $\mathrm{Ca}^{2+}$ have been detected in peat [61].

Calcium extraction was higher in the plants irrigated with tap water $(15.46 \mathrm{~g})$, which is directly related to its concentration in the nutrient and substrate solutions. Calcium levels were the lowest in the $\mathrm{PW}_{4.5}$ and $\mathrm{W}_{9.0}$ plants. It must be taken into account that $\mathrm{S}$ content was very high in pansy plants irrigated with pure leachates, and it has been demonstrated that $\mathrm{SO}_{4}{ }^{2-}$ salinity can reduce plant-available $\mathrm{Ca}^{2+}$ by precipitation of gypsum [66]. On the other hand, a high $\mathrm{Cl}$ content was observed in pansies irrigated with phytodepurated wastewater; similarly, the foliar concentration of Ca dropped in response to a higher accumulation of $\mathrm{Na}$ and $\mathrm{Cl}$ in the foliage of Tilia $\times$ vulgaris $\mathrm{H}$. [67].

\subsubsection{Magnesium}

Magnesium concentrations of 1.67-36.00 ppm of $\mathrm{Mg}^{2+}$ were detected by Alavi et al. [59] in landfill leachates. The concentrations found in the pure wastewaters of this assay fit into this range. The treatment efficiency percentage recorded for hybrid CW systems was 17.24 for $\mathrm{Mg}^{2+}$ [48].

Concerning the $\mathrm{Mg}^{2+}$ concentration in the substrate solution, it was lower than the $\mathrm{Mg}^{2+}$ concentration in the fertigation solution, which indicates that the $\mathrm{Mg}^{2+}$ supply was lower than the plants' requirements. The highest $\mathrm{Mg}^{2+}$ concentration was detected in the substrate irrigated with tap water, due to the lower uptake of pansy plants.

Magnesium extraction was lower with pure wastewater and phytodepurated wastewater; nevertheless, there were no significant differences between the control and the treatments irrigated with $4.5 \mathrm{dS} \mathrm{m}^{-1}$. Both $\mathrm{Ca}^{2+}$ and $\mathrm{Mg}^{2+}$ ions precipitate when combined with $\mathrm{SO}_{4}{ }^{2-}$, and besides this, the excess of $\mathrm{Na}^{+}$and $\mathrm{SO}_{4}{ }^{2-}$ reduces $\mathrm{Mg}^{2+}$ absorption [68], which explains the effects of treatment $\mathrm{W}_{9.0}$ on this cation content in pansy plants. Nevertheless, Manchanda et al. [69] reported an $\mathrm{Mg}^{2+}$ content increased in Festuca arundinacea Schreb. and Medicago sativa L. grown in a calcareous soil with increasing $\mathrm{SO}_{4}{ }^{2-}$ salinity.

\section{Conclusions}

The pure wastewater from open MSWs contains a high concentration of $\mathrm{SO}_{4}{ }^{2-}$ which was highly accumulated in pansy plants tissues, causing toxicity, as it negatively affected the plants' FW, WC (on an FW basis), leaf area, plant height and width, number of leaves and number of flowers. Phytodepuration lowered the $\mathrm{SO}_{4}{ }^{2-}$ concentration in wastewater by half, improving the pansy plants' FW, WC, plant height and width, number of leaves, and number of flowers. Plants irrigated with phytodepurated wastewater extracted high levels of nutrients $(\mathrm{N}, \mathrm{P}$, and $\mathrm{Mg}$ ) when compared with plants irrigated with pure and diluted landfill leachate. The results obtained from the treatments 
tested indicate that the best practice for the reuse of MSW leachate was phytodepuration. This practice promotes the recycling of wastes that are currently treated only as contaminants, with a more useful destination than simply waste treatment and disposal. Future research should be performed on other ornamental and horticultural plants to select the species with a high tolerance to fertigation with these kinds of leachates.

Author Contributions: Conceptualization, A.P. and R.M.; methodology: A.P. and E.B.; formal analysis, B.M.P.; investigation, B.M.P.; resources, A.P.; data curation, B.M.P. and S.J.-B.; writing—original draft preparation, B.M.P.; writing-review and editing, S.J.-B.; visualization, M.T.L.; supervision, M.T.L. and A.P. All authors have read and agreed to the published version of the manuscript.

Funding: This research was funded by the Ministerio de Ciencia, Innovación y Universidades (MICINN) (grant number AP2007-02786).

Acknowledgments: The authors are grateful for the assistance given by Giulia Carmassi, Cecilia Diara, and Luca Botrini with the laboratory work.

Conflicts of Interest: The authors declare no conflict of interest.

\section{References}

1. Zhao, Y.; Wang, Q.; Zang, Y.; Wan, J. Design of intelligent garbage collection system. Adv. Intell. Syst. Comput. 2020, 1017, 542-547.

2. Cebi, S.; Ilbahar, E.; Kahraman, C. An intuitionistic fuzzy axiomatic design approach for the evaluation of solid waste disposal methods. Adv. Intell. Syst. Comput. 2020, 1029, 537-545.

3. Przydatek, G. The analysis of the possibility of using biological tests for assessment of toxicity of leachate from an active municipal landfill. Environ. Toxicol. Phar. 2019, 67, 94-101. [CrossRef]

4. Baruah, D.; Goel, S.; Gupta, C.; Sahu, A.K. Ground improvement using municipal solid waste ash. In Advances in Sustainable Construction Materials and Geotechnical Engineering. Lecture Notes in Civil Engineering; Shukla, S., Barai, S., Mehta, A., Eds.; Springer: Singapore, 2020; Volume 35, pp. 271-280.

5. Cardoso, J.; Gomes, H.T.; Brito, P. Viability of the Use of Leachates from a Mechanical Biological Municipal Solid Waste Treatment Plant as Fertilizers. Recycling 2019, 4, 8. [CrossRef]

6. Gautam, P.; Kumar, S.; Lokhandwala, S. Advanced oxidation processes for treatment of leachate from hazardous waste landfill: A critical review. J. Clean. Prod. 2019, 237, 117639. [CrossRef]

7. EC (European Commission). Report from the Commission to the European Parliament, the Council, the European Economic and Social Committee and the Committee of the Regions. Ninth Report on the Implementation Status and the Programmes for Implementation (as Required by Article 17) of Council Directive 91/271/EEC Concerning Urban Waste Water Treatment. Brussels, 14.12.2017 COM (2017) 749 Final. 2017. Available online: https://eur-lex.europa.eu/legal-content/EN/TXT/?uri=COM:2017:749:FIN (accessed on 22 January 2020).

8. Chen, C.K.; Lo, S.L.; Chen, T.Y. Regeneration and reuse of leachate from a municipal solid waste landfill. J. Environ. Biol. 2014, 35, 1123-1129. Available online: https://www.researchgate.net/profile/Shang-Lien_ Lo/publication/269769743_Regeneration_and_reuse_of_leachate_from_a_municipal_solid_waste_landfill/ links/556d910b08aefcb861d8140b.pdf (accessed on 1 November 2020).

9. Nagendran, R.; Selvam, A.; Joseph, K.; Chiemchaisri, C. Phytoremediation and rehabilitation of municipal solid waste landfills and dumpsites: A brief review. Waste Manag. 2006, 26, 1357-1369. [CrossRef]

10. Xu, Q.; Renault, S.; Yuan, Q. Phytodesalination of landfill leachate using Puccinellia nuttalliana and Typha latifolia. Int. J. Phytoremediat. 2019, 21, 831-839. [CrossRef]

11. Vongdala, N.; Tran, H.D.; Xuan, T.D.; Teschke, R.; Khanh, T.D. Heavy metal accumulation in water, soil, and plants of municipal solid waste landfill in Vientiane, Laos. Int. J. Environ. Res. Public Health 2019, 16, 22. [CrossRef]

12. Kivaisi, A.K. The potential for constructed wetlands for wastewater treatment and reuse in developing countries: A review. Ecol. Eng. 2001, 16, 545-560. [CrossRef]

13. Madera-Parra, C.A.; Peña-Salamanca, E.J.; Peña, M.R.; Rousseau, D.P.; Lens, P.N. Phytoremediation of landfill leachate with Colocasia esculenta, Gynerum sagittatum and Heliconia psittacorum in constructed wetlands. Int. J. Phytoremediat. 2014, 17, 16-24. [CrossRef] 
14. Coyle, D.R.; Zalesny, J.A.; Zalesny, R.S., Jr.; Wiese, A.H. Irrigating poplar energy crops with landfill leachate negatively affects soil micro- and meso-fauna. Int. J. Phytoremediat. 2011, 13, 845-858. [CrossRef] [PubMed]

15. Cataldo, D.A.; Haroon, M.; Schrader, L.E.; Young, V.L. Rapid colorimetric determination of nitrate in plant tissue by nitration of salicylic acid. Comm. Soil Sci. Plant Anal. 1975, 6, 71-80. [CrossRef]

16. Ben Amor, N.; Hamed, K.B.; Debez, A.; Grignon, C.; Abdelly, C. Physiological and antioxidant responses of the perennial halophyte Crithmum maritimum to salinity. Plant Sci. 2005, 168, 889-899. [CrossRef]

17. Lotti, G.; Galoppini, C. Guida alle Analisi Chimice Agrarie. Esercitazioni di Chimica Analitica, Industrie Agrarie e Chimica Agraria, 2nd ed.; Edagricole: Bologna, Italy, 1980.

18. Hocking, P.J.; Pate, J.S. Mobilization of minerals to developing seeds of legumes. Ann. Bot. 1977, 41, 1259-1278. [CrossRef]

19. Dickson, R.; Fischer, P.R. Ammonium-nitrate ratio and cation/anion uptake affect the acidity or basicity of floriculture species. Acta Hortic. 2017, 1168, 135-142. [CrossRef]

20. OJEU (Official Journal of the European Union). Regulation (Eu) 2019/1009 of the European Parliament and of the Council of 5 June 2019 Laying down Rules on the Making Available on the Market of EU Fertilising Products and Amending Regulations (EC) No 1069/2009 and (EC) No 1107/2009 and Repealing Regulation (EC) No 2003/2003. L 170. 25 June 2019, Volume 62. Available online: https://eur-lex.europa.eu/legal-content/ EN/TXT/PDF/?uri=OJ:L:2019:170:FULL\&from=EN (accessed on 22 January 2020).

21. EEA (European Environment Agency). Status of Marine Fish and Shellfish Stocks in European Seas (CSI 032/MAR 007). 2019. Available online: https://www.eea.europa.eu/data-and-maps/indicators/status-ofmarine-fish-stocks-3/assessment-1 (accessed on 22 January 2020).

22. Marschner, H. Marschner's Mineral Nutrition of Higher Plants, 3rd ed.; Academic Press: London, UK, 2012. [CrossRef]

23. Reich, M.; Aghajanzadeh, T.; Helm, J.; Parmar, S.; Hawkesford, M.J.; De Kok, L.J. Chloride and sulfate salinity differently affect biomass, mineral nutrient composition and expression of sulfate transport and assimilation genes in Brassica rapa. Plant Soil 2017, 411, 19-332. [CrossRef]

24. Aghajanzadeh, T.A.; Reich, M.; Hawkesford, M.J.; Burow, M. Sulfur metabolism in Allium cepa is hardly affected by chloride and sulfate salinity. Arch. Agron. Soil Sci. 2019, 65, 945-956. [CrossRef]

25. Hussein, M.M.; Okasha, E.M.; Abdou, M.A.A. Effect of sulfate salinity on growth and photosynthetic pigments of barley varieties. J. Appl. Sci. Res. 2011, 7, 2091-2096. Available online: http://www.aensiweb. com/old/jasr/jasr/2011/2091-2096.pdf (accessed on 23 October 2020).

26. Bie, Z.; Ito, T.; Shinohara, Y. Effects of sodium sulfate and sodium bicarbonate on the growth, gas exchange and mineral composition of lettuce. Sci. Hortic. 2004, 99, 215-224. [CrossRef]

27. Aspinall, D.; Paleg, L.G. Proline accumulation: Physiological aspects. In Physiology and Biochemistry of Drought Resistance in Plants; Paleg, L.G., Aspinall, D., Eds.; Academic Press: Sydney, Australia, 1981; pp. 215-228.

28. Chaparzadeh, N.; Amico, M.L.; Nejad, R.K.; Izzo, R.; Izzo, F.N. Antioxidative responses of Calendula officinalis under salinity conditions. Plant Physiol. Biochem. 2004, 42, 695-701. [CrossRef] [PubMed]

29. Plaza, B.M.; Fusai, F.; Carmassi, G.; Jiménez, S.; Pardossi, A.; Lao, M.T. Effects of treated and untreated wastewater from municipal solid waste (MSW) leachates on the nutritional state of Viola spp.: Sodium, potassium, calcium, and magnesium. Comm. Soil Sci. Plant Anal. 2013, 44, 480-491. [CrossRef]

30. Greenway, H.; Munns, R. Mechanisms of salt-tolerance in nonhalophytes. Annu. Rev. Plant Physiol. 1980, 31, 149-190. [CrossRef]

31. Reginato, M.; Sosa, L.; Llanes, A.; Hampp, E.; Vettorazzi, N.; Reinoso, H.; Luna, V. Growth responses and ion accumulation in the halophytic legume Prosopis strombulifera are determined by $\mathrm{Na}_{2} \mathrm{SO}_{4}$ and $\mathrm{NaCl}$. Plant Biol. 2014, 16, 97-106. [CrossRef] [PubMed]

32. Reich, M.; Aghajanzadeh, T.; Stuiver, C.E.E.; Koralewska, A.; De Kok, L.J. Impact of sulfate salinity on the uptake and metabolism of sulfur in Chinese cabbage. In Molecular Physiology and Ecophysiology of Sulfur; De Kok, L.J., Hawkesford, M.J., Rennenberg, H., Saito, K., Schnug, E., Eds.; Springer: Cham, Switzerland, 2015; pp. 227-238.

33. Datta, K.S.; Kumar, A.; Varma, S.K.; Angrish, R. Differentiation of chloride and sulphate salinity on the basis of ionic distribution in genetically diverse cultivars of wheat. J. Plant Nutr. 1995, 18, 2199-2212. [CrossRef]

34. Llanes, A.; Bertazza, G.; Palacio, G.; Luna, V. Different sodium salts cause different solute accumulation in the halophyte Prosopis strombulifera. Plant Biol. 2013, 15, 118-125. [CrossRef] 
35. Soltanpour, P.N.; Al-Wardy, M.M.; Ippolito, J.A.; Rodriguez, J.B.; Self, J.; Gillaume, M.; Mathews, D. Chloride versus sulfate salinity effects on alfalfa shoot growth and ionic balance. Soil Sci. Soc. Am. J. 1999, 63, 111-116. [CrossRef]

36. Andreo-Martínez, P.; García-Martínez, N.; Almela, L. Domestic wastewater depuration using a horizontal subsurface flow constructed wetland and theoretical surface optimization: A case study under dry Mediterranean climate. Water 2016, 8, 434. [CrossRef]

37. Chen, Y.; Wu, X.; Zhang, Z.; Jiang, L.; Li, K.; Liu, J. Seasonal changes in microbial diversity in different cells of a wetland system constructed for municipal sewage treatment. Acta Ecol. Sin. 2012, 32, 7247-7254. [CrossRef]

38. Abd El-Salam, M.; Abu-Zuid, G.I. Impact of landfill leachate on the groundwater quality: A case study in Egypt. J. Adv. Res. 2015, 6, 579-586. [CrossRef]

39. Hassan, A.H.; Ramadan, M.H. Assessment of sanitary landfill leachate characterizations and its impacts on groundwater at Alexandria. J. Egypt Public Health Assoc. 2005, 80, 27-49. [PubMed]

40. Dev, G.; Kumar, V. Secondary nutrients. In Review of Soil Research in India, Part I, Proceedings of the 12th International Congress of Soil Science, New Delhi, India, 8-16 February 1982; Randhawa, N.S., Ed.; Indian Society of Soil Science: New Delhi, India, 1982; pp. 342-360.

41. Tanner, C.C.; Clayton, J.S.; Upsdell, M.P. Effect of loading rate and planting on treatment of dairy farm wastewaters in constructed wetlands-I. Removal of oxygen demand, suspended solids and faecal coliforms. Water Res. 1995, 29, 17-26. [CrossRef]

42. Beltman, B.; Rouwenhorst, T.G.; Van Kerkhoven, M.B.; Van Der Krift, T.; Verhoeven, J.T.A. Internal eutrophication in peat soils through competition between chloride and sulphate with phosphate for binding sites. Biogeochemistry 2000, 50, 183-194. [CrossRef]

43. Zahoor, A.; Honna, T.; Yamamoto, S.; Irshad, M.; El-Sharkawi, H.; El-Hassan, W.H.A.; Faridullah, F. Wheat response to combined organic and inorganic phosphorus fertilizers application under saline conditions. Acta Agric. Scand. Sect. B-Soil Plant Sci. 2007, 57, 222-230. [CrossRef]

44. Ahmad, Z.; Faridullaha, F.; El-Sharkawi, H.; Irshad, M.; Honna, T.; Yamamoto, S.; Al-Busaidi, A.S. Changes in water-extractability of soil inorganic phosphate induced by chloride and sulfate salts. Environ. Sci. Pollut. Res. 2008, 15, 23-26. [CrossRef]

45. Khorassani, R.; Hettwer, U.; Ratzinger, A.; Steingrobe, B.; Karlovsky, P.; Claassen, N. Citramalic acid and salicylic acid in sugar beet root exudates solubilize soil phosphorus. BMC Plant Biol. 2011, 11, 121. [CrossRef]

46. Plaza, B.M.; Soriano, F.; Jiménez-Becker, S.; Lao, M.T. Nutritional responses of Cordyline fruticosa var. 'Red Edge' to fertigation with leachates vs. conventional fertigation: Chloride, nitrogen, phosphorus and sulphate. Agric. Water Manag. 2016, 173, 61-66. [CrossRef]

47. Ahmadi, M.; Souri, M.K. Growth and mineral content of coriander (Coriandrum sativum L.) plants under mild salinity with different salts. Acta Physiol. Plant. 2018, 40, 194. [CrossRef]

48. Ali, Z.; Mohammad, A.; Riaz, Y.; Quraishi, U.M.; Malik, R.N. Treatment efficiency of a hybrid constructed wetland system for municipal wastewater and its suitability for crop irrigation. Int. J. Phytoremediat. 2018, 20, 1152-1161. [CrossRef]

49. Farid, M.; Irshad, M.; Fawad, M.; Awan, Z.A.; Eneji, A.E.; Aurangzeb, N. Effect of cyclic phytoremediation with different wetland plants on municipal wastewater. Int. J. Phytoremediat. 2014, 16, 572-581. [CrossRef]

50. Villarino, G.H.; Mattson, N.S. Assessing tolerance to sodium chloride salinity in fourteen floriculture species. Horttechnology 2011, 21, 539-545. [CrossRef]

51. Charriau, A.; Bordas, F.; Rabiet, M.; Guibaud, G. Evaluation, through the measurements of electric conductivity and mineral compound contents in waters and soils, of the impact of an old municipal landfill on a wetland (peat bog). Eur. J. Water Qual. 2013, 44, 13-38. [CrossRef]

52. Saeed, T.; Sun, G. A review on nitrogen and organics removal mechanisms in subsurface flow constructed wetlands: Dependency on environmental parameters, operating conditions and supporting media. J. Environ. Manag. 2012, 112, 429-448. [CrossRef]

53. Aguirre, P.; Ojeda, E.; Garcia, J.; Barragan, J.; Mujeriego, R. Effect of water depth on the removal of organic matter in horizontal subsurface-flow constructed wetlands. J. Environ. Sci. Health 2005, 40, 1457e1466. [CrossRef]

54. Garcia, J.; Aguirre, P.; Barragan, J.; Mujeriego, R.; Matamoros, V.; Bayona, J.M. Effect of key design parameters on the efficiency of horizontal subsurface-flow constructed wetlands. Ecol. Eng. 2005, 25, 405. [CrossRef] 
55. Cerović, Z.G.; Kalezić, R.; Plesničar, M. The role of photophosphorylation in $\mathrm{SO}_{2}$ and $\mathrm{SO}_{3}{ }^{2-}$ inhibition of photosynthesis in isolated chloroplasts. Planta 1982, 156, 249-254. [CrossRef]

56. Rennenberg, H. 1984. The fate of excess sulfur in higher plants. Ann. Rev. Plant Physiol. 1984, 35, 121-153. [CrossRef]

57. Ryrie, I.J.; Jagendorf, A.T. Inhibition of photophosphorylation in spinach chloroplasts by inorganic sulfate. J. Biol. Chem. 1971, 246, 582-588.

58. Chofqi, A.; Younsi, A.; Lhadi, E.; Mania, J.; Mudry, J.; Veron, A. Environmental impact of an urban landfill on a coastal aquifer (El Jadida, Morocco). J. Afr. Earth Sci. 2004, 39, 509-516. [CrossRef]

59. Alavi, N.; Eslami, A.; Saghi, M.H. Measurement and monitoring of anions, cations and metals in landfill leachate in Iranian metropolises. Data Brief 2018, 21, 1818-1822. [CrossRef]

60. Lopes-Cruz, J.L.; Alves, A.; Ferreira, E.; Coelho, M.A. Under salinity the 'Prata Anã Gorutuba' clone restrices $\mathrm{Na}^{+}$uptake and its accumulation in leaves. Sci. Hortic. 2020, 270, 109426. [CrossRef]

61. Carmo, D.L.; Lima, L.B.; de Silva, C.A. Soil fertility and electrical conductivity affected by organic waste rates and nutrient inputs. Rev. Bras. Cienc. Solo 2016, 40, e0150152. [CrossRef]

62. Tester, M.; Davenport, R. $\mathrm{Na}^{+}$tolerance and $\mathrm{Na}^{+}$transport in higher plants. Ann. Bot. 2003, 91, 503-527. [CrossRef]

63. Munns, R.; Tester, M. Mechanisms of salinity tolerance. Annu. Rev. Plant Biol. 2008, 59, 651-681. [CrossRef] [PubMed]

64. Craig Plett, D.; Møller, I.S. $\mathrm{Na}^{+}$transport in glycophytic plants: What we know and would like to know. Plant Cell Environ. 2010, 33, 612-626. [CrossRef]

65. Cabot, C.; Sibole, J.V.; Barceló, J.; Poschenrieder, C. Lessons from crop plants struggling with salinity. Plant Sci. 2014, 226, 2-13. [CrossRef]

66. Ströhmenger, P.H.E. Interactive Effects of Calcium and Magnesium Sulphate Enriched Waste Water on Crop Growth and Nutrition. Master's Thesis, University of Pretoria, Pretoria, South Africa, 2001. Available online: https://repository.up.ac.za/handle/2263/23599 (accessed on 12 October 2020).

67. Cekstere, G.; Osvalde, A.; Elferts, D.; Rose, C.; Lucas, F.; Vollenweider, P. Salt accumulation and effects within foliage of Tilia $\times$ vulgaris trees from the street greenery of Riga, Latvia. Sci. Total Environ. 2020, 747, 140921. [CrossRef]

68. Gomes, M.A.D.C.; Suzuki, M.S.; Cunha, M.D.; Tullii, C.F. Effect of salt stress on nutrient concentration, photosynthetic pigments, proline and foliar morphology of Salvinia auriculata Aubl. Acta Limnol. Bras. 2011, 23, 164-176. [CrossRef]

69. Manchanda, H.R.; Sharma, S.K.; Mor, R.P. Relative tolerance of pulses for chloride and sulphate salinity. Indian J. Agric. Sci. 1991, 61, 20-26. [CrossRef]

Publisher's Note: MDPI stays neutral with regard to jurisdictional claims in published maps and institutional affiliations.

(C) 2020 by the authors. Licensee MDPI, Basel, Switzerland. This article is an open access article distributed under the terms and conditions of the Creative Commons Attribution (CC BY) license (http://creativecommons.org/licenses/by/4.0/). 